\title{
Outcome of intraoperative use of mitomycin $C$ combined with conjunctival auto graft in recurrent pterygium
}

\author{
MK Goswami, F Hossain, AB Shamsudduha, M Asaduzzaman \\ Department of Ophthalmology, Bangladesh Institute of Research and Rehabilitation in Diabetes, \\ Endocrine and Metabolic Disorder (BIRDEM), Dhaka
}

\begin{abstract}
Background and objectives: Recurrent pterygium is an important ocular problem in our country. There are different modalities of treatment for recurrent pterygium. The present study was undertaken to determine the effect of intraoperative mitomycin $\mathrm{C}$ along with conjunctival auto graft to prevent recurrence of pterygium.

Methods: Patients with recurrent pterygium attending a tertiary care hospital in Dhaka from January 2013 to June 2015 were included in the study. Cases were randomized into two groups. Group 1 had pterygium surgery with conjunctival auto graft and Group 2 had auto graft and intraoperative mitomycin C $(0.02 \%)$. All cases were followed up for one year to assess recurrence of pterygium.
\end{abstract}

Results: A total of 54 recurrent pterygia cases were included in the study. The age of study population was 25 to 65 years. The recurrence rate of pterygium after 12 months was $77.7 \%$ in group 1 and none in group 2. No major postoperative complication was observed.

Conclusion: The study demonstrated that the use of intraoperative mitomycin $\mathrm{C}$ along with conjunctival auto graft had significant effect in preventing the recurrence of pterygium.

IMC J Med Sci 2016; 10(2): 49-52

\section{Introduction}

Recurrent pterygium is an important ocular disorder. Many medical treatments have been described but surgical excision of the pterygium is the mainstay of treatment. Numerous surgical techniques like conjunctival auto graft with or without the use of adjuncts like beta irradiation, intra or postoperative mitomycin $\mathrm{C}$ or anti neoplastic agents have been described. In the last decade mitomycin $\mathrm{C}$, an antineoplastic agent that selectively inhibits the synthesis of DNA, cellular RNA, and protein $[1,2]$ has been used in conjunction with surgery in the treatment of glaucoma filtering procedures and in pterygium surgery. In filtering procedures for glaucoma patients, the rate of bleb failures has decreased and the surgical outcome of previously failed filters has improved by the application of mitomycin C [3, 4]. No ocular surface related complications of mitomycin $\mathrm{C}$ in filtering procedures have been reported. Mitomycin $\mathrm{C}$ has also been used in pterygium surgery. Postoperative administration of topical $0.02 \%$ to $0.1 \%$ mitomycin $\mathrm{C}$ drops decreased the recurrence rate of pterygium to a range of $2 \%$ to $11 \%$ [5-8]. However, postoperative complications were reported even when a low dosage of mitomycin was applied $[8,9]$. The major reasons for complications were related to uncontrolled and prolonged use of the drug by the patients [9]. A single intra operative application of topical mitomycin $\mathrm{C}$ during the excision of pterygium has decreased the recurrence rate of

Address for Correspondence:

Dr. Manash Kumar Goswami, Associate Professor, Department of Ophthalmology, BIRDEM General Hospital, 122 Kazi Nazrul Islam Avenue, Shahbag,Dhaka.Email: manashkg@yahoo.com 
pterygium as well as the rate of complications [1012]. Conjunctival auto transplantation is a common procedure for primary and recurrent pterygium, with recurrence rates ranging from $2 \%$ to $39 \%$ [13-18]. Conjunctival auto transplantation combined with adjunctive mitomycin $\mathrm{C}$ for primary and recurrent pterygium was reported in two previous studies, with a recurrence rate of $2 \%$ to $9 \%[17,19,20]$.

In the present study, we report our experience on the outcome of recurrent pterygium excision with conjunctival auto grafting combined with intra operative application of mitomycin $\mathrm{C}$.

\section{Material and Methods}

Study population and place: The study was conducted at the Department of Ophthalmology, Bangladesh Institute of Research and Rehabilitation in Diabetes, Endocrine and Metabolic Disorders (BIRDEM), Dhaka from January 2013 to June 2015. Patients with recurrent pterygium aged 25 to 65 years were enrolled in the study. Recurrent pterygium was defined as re-growth of same pterygium after surgical excision with or without graft. Patients with primary pterygia, atypical pterygia, ocular surface disorders and coagulation abnormalities were excluded. Informed consent was obtained from each patient following a detailed explanation of all of the surgical procedures.

Study design: Enrolled patients were equally and randomly divided into two groups. Group 1 underwent pterygium surgery with conjunctival auto graft alone and Group 2 had conjunctival auto graft and intraoperative mitomycin $\mathrm{C}$ upon completion of pterygium removal. In this group each case received a single intraoperative dose of mitomycin C $(02 \%)$. Mitomycin C, soaked in a sterile sponge, was applied for one minute to the sclera bed after removing the pterygium. All the patients were operated by the same surgeon and $10 / 0$ nylon was used to secure the graft. Following the surgery, each patient was treated with topical corticosteroid four times daily for 7 days. Corticosteroid was tapered and discontinued after three months. Topical antibiotics were used until epithelialization of the wound was complete. Patients were examined at day $1,7,15,30$, and 90, and then at three-month intervals up to one year. Recurrence was diagnosed when vessels invaded through the limbal area into the clear cornea [21].

\section{Results}

A total of 54 cases with recurrent pterygium were included in the study. Each group had 27 patients. Table-1 shows the features of study population. The distribution of male and female in group 1 was $77.8 \%$ and $22.2 \%$ and in group 2 was $70.4 \%$ and $29.6 \%$. Age of the study population ranged between 25 to 65 years and the mean age of the group 1 and 2 cases were $43.4 \pm 12.2$ and $41.8 \pm 11.8$ years respectively. The patients were followed for more than one year following surgery. Postoperatively, the conjunctival auto graft had mild to moderate edema, which subsided within the first three to four weeks. In both the mitomycin C treated and non-treated auto grafts, the formation of anastomotic connections in the transplant started between one and two weeks after surgery. Sutures were re-moved after 3 to 4 weeks, when anastomotic vessels were found all around the graft. After one year, pterygium recurred in 21 patient $(77.7 \%)$ in group 1 and there was no recurrence in group 2 (Table-1).

Table-1: Features of study population and outcome of conjunctival auto graft plus mitomycin $C$

\begin{tabular}{llc}
\hline \multicolumn{1}{c}{$\begin{array}{c}\text { Study } \\
\text { population }\end{array}$} & $\begin{array}{c}\text { Group 1 } \\
\text { Number (\%) }\end{array}$ & $\begin{array}{c}\text { Group 2 } \\
\text { Number (\%) }\end{array}$ \\
\hline Total patients & 27 & 27 \\
$\begin{array}{l}\text { Male } \\
\text { Female }\end{array}$ & $21(77.8)$ & $19(70.4)$ \\
$\begin{array}{l}\text { Recurrence of } \\
\text { pterygium after }\end{array}$ & $6(22.2)$ & $8(29.6)$ \\
\begin{tabular}{l}
1 year \\
\hline
\end{tabular} & $21(77.7)$ & 0 \\
\hline
\end{tabular}

Group $1=$ Conjunctival auto graft only;

Group $2=$ Conjunctival auto graft plus intraoperative mitomycin $C$.

\section{Discussion}

Pterygium surgery has changed over the past decade, and several techniques are now available. Our study presents the efficacy of intraoperative use of mitomycin $\mathrm{C}$ along with conjunctival auto 
grafting to reduce the recurrence of pterygium with minimal postoperative complications.

In pterygium surgery, daily administration or single intraoperative use of a variety of mitomycin $\mathrm{C}$ doses have been reported [5-8, 10-12, 22, 23]. However, the safest dosage of mitomycin $\mathrm{C}$ that can prevent the recurrence of pterygium without causing complications is still unknown. Postoperative use of topical mitomycin $\mathrm{C}$ is not recommended because of a possible drug misuse, which may cause severe ocular complications such as scleromalacia, corneal perforation, glaucoma, iritis, pain, and punctate keratopathy [6-9]. Single intraoperative use of mitomycin $\mathrm{C}$ has been found safer than postoperative topical daily application [10-12, 24].

The recurrence rate of primary and recurrent pterygia treated with mitomycin $\mathrm{C}$ was approximately $6.7-22.5 \%$ over different period of time, and only mild complications such as superficial punctate keratopathy and mild avascularity of the bare sclera area were observed $[25,26]$. A study has recently demonstrated normal sclera thickness and conjunctival epithelial phenotype at the surgical site more than six years after pterygium surgery with mitomycin C [27]. When bare sclera technique is performed in a patient with normal ocular surface, the epithelialization of the wound area is usually completed within 7 to 14 days [10, 11]. Intact epithelium over the operated area is necessary to prevent scleral melting after pterygium surgery when mitomycin $\mathrm{C}$ is used. To prevent scleral melting, we kept the conjunctiva overlying the body of the pterygium and sutured it back to the sclera at the end of the procedure.

To avoid severe ocular complications, patients with abnormal ocular surface who were at greater risk for a delay of epithelialization or excessive inflammation, such as patients with immune disorders, blepharitis or dry eyes, were excluded from our studies. Furthermore, postoperatively, we closely observed the patients until the epithelialization of the ocular surface was complete.

In the present study, we found that conjunctival auto graft with single application of intraoperative mitomycin $\mathrm{C}$ had no post operative recurrence after 12 months of surgery while the recurrence rate was $77.7 \%$ among the patients where only grafting was performed without mitomycin C. Therefore, conjunctival auto grafting combined with intraoperative application of $0.02 \%$ mitomycin $\mathrm{C}$ for one minute was more effective than conjunctival auto grafting alone. However, it is important to observe the recurrence rate in recurrent pterygium treated with single application of intraoperative mitomycin $\mathrm{C}$ over longer period of time.

\section{Reference}

1. Chabner BA, Amrein PC, Druker BJ, Michaelson CS, Mitsiades CS, Goss PE, et al. Chemotherapy of neoplastic diseases. In: Brunton LL, Lazo JS, Parker KL, editors. Goodman Gilman's the pharmacological basis of therapeutics. New York: McGraw-Hill; 2006. p.1315-1404.

2. Verweij J, Pinedo HM. Mitomycin C: mechanism of action, usefulness and limitations. Anticancer Drugs 1990; 1(1): 5-13.

3. Chen CW, Huang HT, Bair JS, Lee CC. Trabeculectomy with simultaneous topical application of mitomycin C in refractory glaucoma. J Ocul Pharmacol 1990; 6(3): 175182.

4. Palmer SS. Mitomycin C as adjunct chemotherapy with trabeculectomy. Ophthalmology 1991; 98(3): 317-321.

5. Singh G, Wilson MR, Foster CS. Long-term follow-up study of mitomycin eye drops as adjunctive treatment of pterygia and its comparison with conjunctival autograft transplantation. Cornea 1990; 9(4): 331-334.

6. Hayasaka S, Noda S, Yamamoto Y, Setogawa T. Postoperative instillation of low-dose mitomycin $\mathrm{C}$ in the treatment of primary pterygium. Am J Ophthalmol 1988; 106(6): 715-718.

7. Singh G, Wilson MR, Foster CS. Mitomycin eye drops as treatment for pterygium. Ophthalmology 1988; 95(6): 813-821.

8. Hayasaka S, Noda S, Yamamoto Y, Setogawa T. Postoperative instillation of mitomycin $\mathrm{C}$ in 
the treatment of recurrent pterygium. Ophthalmic Surg 1989; 20(8): 580-583.

9. Rubinfeld RS, Pfister RR, Stein RM, et al. Serious complications of topical mitomycin C after pterygium surgery. Ophthalmology 1992; 99(11): 1647-1654.

10. Frucht-Pery J, Ilsar M, Hemo I. Single dosage of mitomycin $\mathrm{C}$ for prevention of recurrent pterygium: preliminary report. Cornea 1994; 13(5): 411-413.

11. Frucht-Pery J, Siganos CS, Ilsar $M$. Intraoperative application of topical mitomycin C for pterygium surgery. Ophthalmology 1996; 103(4): 674-677.

12. Mastropasqua L, Carpineto P, Ciancaglini M, Lobefalo L, Gallenga PE. Effectiveness of intraoperative mitomycin $\mathrm{C}$ in the treatment of recurrent pterygium. Ophthalmologica 1994; 208(5): 247-249.

13. Kenyon KR, Wagoner MD, Hettinger ME. Conjunctival autograft transplantation for advanced and recurrent pterygium. Ophthalmology 1985; 92(11): 1461-1470.

14. Lewallen $\mathrm{S}$. A randomized trial of conjunctival autografting for pterygium in the tropics. Ophthalmology 1989; 96(11): 1612-1614.

15. Chen PP, Ariyasu RG, Kaza V, LaBree LD, McDonnell PJ. A randomized trial comparing mitomycin $\mathrm{C}$ and conjunctival autograft after excision of primary pterygium. $\mathrm{Am} J$ Ophthalmol 1995; 120(2): 151-160.

16. Riordan-Eva P, Kielhorn I, Ficker LA, Steele $\mathrm{AD}$, Kirkness CM. Conjunctival autografting in the surgical management of pterygium. Eye 1993; 7(5): 634-638.

17. Mutlu FM, Sobaci G, Tatar T, Yildirim E. A comparative study of recurrent pterygium surgery: limbal conjunctival autograft transplantation versus mitomycin $\mathrm{C}$ with conjunctival flap. Ophthalmology 1999; 106: 817-821.
18. Ti SE, Chee SP, Dear KB, Tan DT. Analysis of variation in success rates in conjunctival autografting for primary and recurrent pterygium. Br J Ophthalmol 2000; 84: 385- 389.

19. Wong VA, Law FC. Use of mitomycin $C$ with conjunctival autograft in pterygium surgery in Asian-Canadians. Ophthalmology 1999; 106(8): 1512-1515.

20. Segev F, Jaeger-Roshu S, Gefen-Carmi N, Assia EI. Combined mitomycin C application and free flap conjunctival autograft in pterygium surgery. Cornea 2003; 22: 598- 603.

21. Joseph FP, Frederic R, Michael I, David L, Faik O, Abraham S. Conjunctival auto grafting combined with low-dose mitomycin $\mathrm{C}$ for prevention of primary pterigyum recurrence. Am J Ophthalmol 2006; 141(6): 1044-1050.

22. Mahar PS, Nwokora GE. Role of mitomycin $\mathrm{C}$ in pterygium surgery. $\mathrm{Br} J$ Ophthalmol 1993; 77: 433-435.

23. Frucht-Pery J, Ilsar M. The use of low-dose mitomycin C for prevention of recurrent pterygium. Ophthalmology 1994; 101: 759-762.

24. Raiskup F, Solomon A, Landau D, et al. Mitomycin $\mathrm{C}$ for pterygium: long-term evaluation. $\mathrm{Br} \quad J$ Ophthalmol 2004; 88: 1425-1428.

25. Lam DS, Wong AK, Fan DS, Chew S, Kwok $\mathrm{PS}$, Tso MO. Intraoperative mitomycin $\mathrm{C}$ to prevent recurrence of pterygium after excision: a 30-month follow-up study. Opthalmology 1998; 105(5): 901-905.

26. Martins TGS, de Azeverdo Costa ALF, Alves MR, Chammas R, Schor P. Mytomicin C in pterygium treatment. Int J Ophthalmol 2016; 9(3): 465-468.

27. Solomon A, Kaiserman I, Raiskup FD, et al. Long-term effects of mitomycin $\mathrm{C}$ in pterygium surgery on sclera thickness and the conjunctival epithelium. Ophthalmology 2004; 111(8): 1522-1527. 